\title{
Seasonal Migration as a Livelihood Strategy of Women Agricultural Labourers in Soul Ponamara Mouza of Hirbandh Block, Bankura District, West Bengal
}

\author{
Debmita Nandi ${ }^{+*}$ and Sumana Sarkar ${ }^{¥}$
}

\section{Abstract}

Seasonal migration is a common livelihood strategy among marginal and landless people of the western part of West Bengal. The National Sample Survey Organisation (NSSO) and Census data have failed to provide information on seasonal migration and livelihoods at the micro-level. The present study focuses on the nature, characteristics and factors of seasonal migration with its importance as a livelihood strategy among women agricultural labourers (WALs) in Soul Ponamara mouza of Hirbandh block at the micro-level. The study is based on primary data collection using a purposive sampling method and a semi-structured questionnaire, personal interview and focus group discussion. This study reveals that seasonal migration from Soul Ponamara to the adjacent agriculturally prosperous districts viz. Purba Bardhaman and Hooghly (4 to 6 times in a year) is a common livelihood strategy among WALs in the study area, and its proportion is almost equal to when compared to male migrants. The small size of agricultural land holding, existing monoculture system, lack of irrigation facilities, a limited job opportunity in the Soul Ponamara mouza and its surrounding area (Amjhuri, Bijardihi, Chaka Doba, Moshiara, Bamni and Rangametia) provoke women labourers to move out in searching of works. In contrast, high wage and massive demand for skilled and semiskilled agricultural labourers during sowing and harvesting season in the destination area, that is, paddy and potato fields of Purba Bardhaman and Hooghly districts acted as a magnet to absorb these immigrants into the workforce. This study concludes that seasonal migration opted for employment and income generation is the primary livelihood strategy adopted by the rural WALs of this mouza to cope up with the existing poverty and food insecurity.

Keywords: Livelihood Strategy; Agricultural Labourers; Seasonal Migration; Poverty; Food Insecurity; Soul Ponamara Mouza; Hirbandh; Bankura; West Bengal; India

\footnotetext{
' Senior Research Fellow, Department of Geography, The University of Burdwan, Burdwan, West Bengal , India ${ }^{*}$ Corresponding Author, Email: debmitanandi2012@gmail.com

${ }^{\sharp}$ Assistant Professor, Department of Geography, The University of Burdwan, West Bengal, India, Email: sumanasarkar83@gmail.com

(C) 2020 Nandi \& Sarkar. This is an Open Access article distributed under the terms of the Creative Commons Attribution License (http://creativecommons.org/licenses/by/2.0), which permits unrestricted use, distribution, and reproduction in any medium, provided the original work is properly cited.
} 


\section{Introduction}

Temporary or seasonal migration is a short-term, repetitive or circular migration with a motive of a temporary change of residence (Zelinsky, 1971). Socioeconomically backward and landless people (SEBLP) of the rural area seasonally migrate to the nearest prosperous region because of unbalanced economic growth (Berchoux et al., 2019; Debnath, 2020; Debnath and Nayak, 2020; Islam et al., 2019; Keshri and Bhagat, 2010) and absence of duty in the family farm (Lindstrom and Ramirez, 2010; Mishra, 2020). It is very popular, especially in the slack season of agriculture to cope up with the poverty and unemployment (Debnath and Nayak, 2020; Ellis, 2008; Gill, 2003; Mishra, 2016; Serrat, 2017).

In India, seasonal migration of agricultural labourers is an essential process among SEBLP for their survival in the slack season (De Haan, Brock \& Coulibaly, 2002; Keshri and Bhagat, 2013; Singh et al., 2011; Sundari, 2005). Their mobility is linked either directly or indirectly with the seasonal trough in the agricultural production cycle of the home region (Agarwal, 1990; Beck, 1989) and it follows the rhythm of crop harvest cycles in migrant destinations and home villages (Rai, 2020). Uttar Pradesh, Maharashtra, Bihar, West Bengal, Orissa are the dominant states of seasonal migration where young rural people used to migrate during the season of crop harvesting and sowing with least women participation (Rai, 2020; Thapa and Yadav, 2015). According to Ravenstein's Law of Migration (1889), women migration occurs mainly in a short distance and for the economic cause. In a similar context, one may argue that the seasonal migrations of women agricultural labourers (WALS) are limited to the nearby prosperous region.

Approximately 25 per cent of the households of India have at least one migrant (Gundappa and Dsouza, 2014). The National Sample Survey Organization (NSSO) and Census of India are the two reliable sources in India for supplying migration data. However, these are not able to provide information related to seasonal migration and livelihood (Chandrasekhar and Ghosh, 2007; Kesheri and Bhagat, 2010; Kesheri and Bhagat, 2012). In earlier studies, though some aspects of seasonal migration were explored, for examples, stream of migration (Rogaly et al., 2002), changes of social relationship and migration as a livelihood option (Rogaly, 2010) but less attention was given to the sole aspect of engagement of WALs in seasonal migration and livelihood strategy practiced by them at the micro-level.

This study starts with a concise literature review, which analyses the earlier work on women agricultural labourers and livelihood strategies to recognise the research gap and specific objectives. It provides arguments behind the selection of the specific area. Thereafter, a detailed methodology and source of the data have been described. The next section explains the nature and characteristics of seasonal migration, followed by the factors associated with it and their livelihood strategy. The main findings and significance of the study have been summarised in the conclusion section.

\section{Literature Review}

Studies of Deshingkar and Daniel (2003), Islam et al. (2019), Keshri and Bhagat (2010), Khatun and Roy (2016), Rafique (2003), Rai (2020), Rogaly and Coppard (2003) and Rogaly et al. (2001) have shown the importance of seasonal migration in livelihood strategies of the SEBLP in rural areas and has been increasingly becoming an accumulative alternative for them. Numerous studies (Debnath, 2020; Garikipati, 2008; Ghosh and Mal, 2017; Keshri and Bhagat, 2010; Keshri and Bhagat, 2012; Rademacher-Schulz et al., 2014; Rafique, 2003; Rogaly and Coppard, 2003; Rogaly et al., 2001) have pointed out several factors of seasonal migration, where job opportunities and poverty are the primary reasons behind seasonal migration.

The economic benefit of the seasonal migration also has been discussed in earlier studies like Garikipati (2008), Gautam (2017), Keshri and Bhagat (2010), Mishra (2016) and Sundari (2005). Rogaly et al. (2001), Rogaly (2010) and 
Sundari (2005) discussed the causes of seasonal migration - landless condition, unemployment and lack of job opportunity in a residential area, and employment opportunity and higher wage in the destination area. They have also pointed out that this type of temporal migration is highly seasonal and kinship in nature and is associated with several problems - irregularity in income and food consumption, health problem, poor sanitation and lack of social security. Besides, Rogaly et al. (2001), Rogaly (2010) and Sundari (2005) have discussed the role of seasonal migration in livelihood strategies for both men and women. However, specifically, the cases of WALs have got lesser importance. So, seasonal migration as a livelihood strategy of WALs is very relevant to study.

Besides, in our country, there is a considerable amount of inter-state disparity in poverty mitigation programmes and possession of agricultural land, and it is rigorously affecting the livelihood of rural poor in general and women's in particular (Chandrasekhar and Sahoo, 2018; Garikipati, 2008; Panda and Agarwal, 2005; Panda and Mishra, 2018). Thereby, women are compelled to depend on agricultural wage work through which rural poor women might sustain their families (Garikipati, 2008). Besides, numbers of WALS in India increased from $25.6 \%$ to $43.4 \%$ over the period 1961-2001 (Garikipati, 2008). According to the Census of India (2011), the percentage of WALS has increased to $48.5 \%$ (59.06 million), which is approximately 5.1\% higher than the 2001 census. Besides, higher wages, reducing female-male wage gap, increasing labour demand and general improvement in working circumstances in receiving places of seasonal migrants (Hazell and Ramasamy, 1991; Hussain et al., 2020; Walker and Ryan, 1990) and lack of job opportunities in the source area have encouraged impelling them to migrate seasonally along with male members (Garikipati, 2008). Seasonal migration of agricultural labourers in eastern India is very high, and especially in the Burdwan district of West Bengal, which alone receives about 0.5 million of seasonal migrant labourers per year to work associated with rice cultivation. This is because of widespread development of canal and private groundwater irrigation system after the 1980s creating a huge demand for agricultural labourers and number of women participants are similar to the male (Rogaly et al., 2002). Though some study (Asfaw et al., 2010; Thapa and Yadav, 2015) have shown that women's participation in seasonal migration for employment is negligible and stands merely at $3 \%$ in India, the latest available census data shows an increasing trend of rural to a rural movement among women for work. Apart from this, the existing literature has discussed seasonal migration as a livelihood strategy in macro-level where limited weightage is given to gender-based micro-level study. In similar contexts, the central objectives of this study are to discuss the nature and characteristics of seasonal migration among rural women agricultural labourers and to identify factors behind it at micro-level; and to explore how seasonal migration acted as a livelihood strategy for them.

District Human Development Report (DHDR) (2007) reported that rural to rural seasonal migration is a widespread phenomenon among the SEBLP of the eight community development blocks (Bankura-I, Indpur, Saltora, Chhatna, Ranibandh, Khatra, Hirbandh and Sarenga) in Bankura district. The SEBLP (Bauri, Santal, Bhumij and Mahato) of this area seasonally migrates to the Burdwan and Hooghly districts to work as an agricultural labourer (Rogaly et al., 2002). Therefore, to fulfil the above-mentioned objectives, the study was conducted after purposefully selecting Soul Ponamara mouza in Hirbandh of Bankura district as a case.

\section{Study Area}

Hirbandh block is an extended part of Chotanagpur plateau fringe in the western portion of Bankura district characterised by an undulating surface with the dry condition and lack of irrigation facilities. Soul Ponamara mouza (JL No. 55) of Moshiara Gram Panchayet of this block is a backward mouza with 70 households and 313 total populations and home to 93\% Scheduled Caste (Bauri) population, who are officially designated groups of people in India generally associated with depressed classes of 
the society. Among the total working population of this village, $99.45 \%$ are engaged as agricultural labourers where $99 \%$ male workers and $100 \%$ women workers participated in agriculture labour activity (District Primary Census Abstract, 2011). The maximum amount of monsoon rainfall (80\%) in this district occurs in the month of June to September (DSH, 2014) with erratic in nature (DHDR, 2007). Among the total area of 161.4 hectares of land, 75.3 hectares (46.65\%) are the net sown area where only 10 hectares $(7.53 \%)$ of agricultural land has irrigation facilities (District Village Directory, 2011). Hence, rain-fed monoculture ( $A m$ mon $^{1}$ Paddy) is mainly practiced here on the lateritic type of soil (National Bureau of Soil Survey and Land Use Planning Department, 2010). Some $R a b i^{2}$ crop is also (November to April) cultivated in small patches of agricultural land with the uncertainty of winter monsoon rainfall at subsistence level (DHDR, 2007). The women labour force of this mouza is dependent upon agricultural labour work and tends to move in distance places (Figure 1).

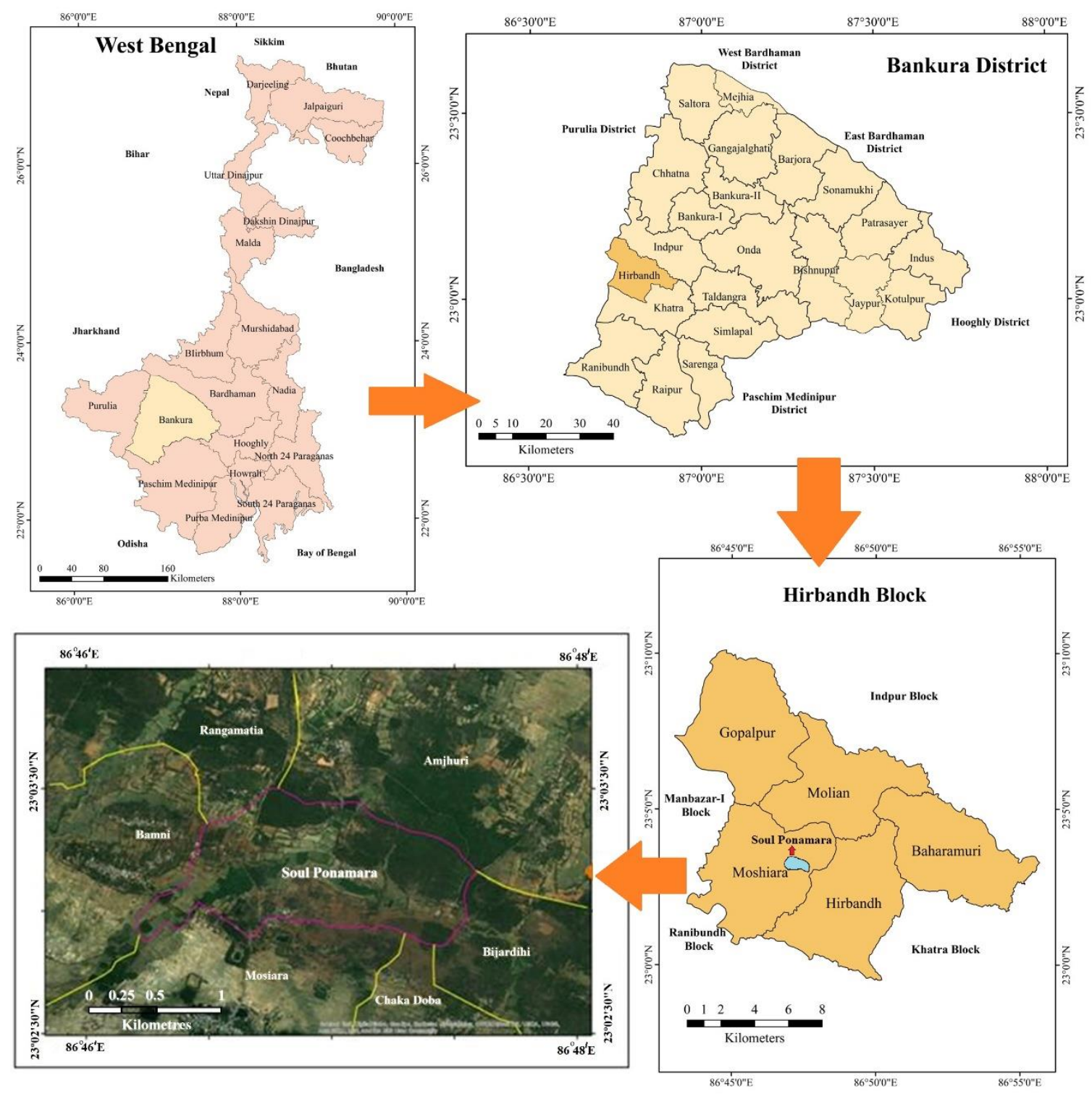

Figure 1: Location Map of Study Area Source: Prepared by Authors

\footnotetext{
${ }^{1} A$ mon or monsoonal rice in India is cultivated during June to November under rain-fed condition (Adhikari et al. 2011).
}

${ }^{2}$ Rabi crops are winter agricultural crops in India, which is generally cultivated from November to March (Husain, 1996). 


\section{Methodology}

The study is principally based on field survey and supplemented by secondary data, which has been collected from District Primary Census Abstract (DPCA, 2011), District Human Development Report (DHDR, 2007), District Village Directory (DVD, 2011), Land and Land Reform Department (2013) and District Statistical Handbook (DSH, 2014). Thirty women agricultural labourers have been purposively selected as respondents from 30 households for the personal interview and focus group discussion (FGD). These 30 participants were selected from 92 women agricultural labourers (DPCA, 2011) who were the sole women breadwinners in their family and used to migrate across the district borders. The personal interview helped to collect socio-economic data of livelihood strategy and three FGDs with 8, 9 \& 13 persons respectively helped to ascertain about the nature, characteristics and factors of seasonal migration which is mostly qualitative. Native Bengali language was adopted for smooth conversation (personal interview and focus group discussion) during data collection, and then the conversation was translated into English maintaining its literal sense (Filep, 2009; Regmi et. al 2010; Temple and Young, 2004). Field surveys were conducted twice - the first one in the lean season (April 2018) and the other in the time of peak season (November 2018) to obtain the data of seasonal migration throughout the year.

\section{Results and Discussion}

\section{Nature and Characteristics of Seasonal Migration}

Rural women of the study area used to migrate to Burdwan and Hooghly districts during sowing and harvesting seasons of Amon, Boro ${ }^{3}$ paddy and potato. They migrate as a group of $10-15$ members where both the male and female workers participate in a more or less equal number, and the group is headed by a male Sardar. ${ }^{4}$ Dominant age-group of the women labourers is 35-45 years, and their seasonal migrations depend on the presence of male members in the team. Sardar takes the responsibility to communicate and bargain with the landlords related to work assignment, wages level and working days. He enjoys a relatively higher wage and status than the other members. Earlier, they prefered to migrate as agricultural labourers to the same landlord because of the known environment and lack of transport and limited network facilities in between the source and the destination areas. Nevertheless, nowadays, with the infrastructural development and expansion of social networking, they are more concerned about higher wage rate and availability of a number of working days in agricultural activities rather than travelling distances. They now migrate for four to six times a year, and the total duration is about 3-4 months within a year. They called it in Bengali language as Pube jaua. ${ }^{5}$ Pregnant women used to migrate, but their frequency of movement is less in nature. Small children (below 7 years) also migrate with their mother, and as a result, the school-going children discontinue their schooling, thereby contributing to increasing in dropout level in the schools which ultimately results into the continuation of the poverty cycle. During this period the household activities of the respondents are managed by the aged members (>55 years) and other children (7-15 years), especially girls and some neighbourhood people. Similar findings were also observed by Biswal (2020) in the context of western Odisha, India and Rogaly et al., (2002) citing the case of eastern India, especially in West Bengal.

\footnotetext{
${ }^{5}$ Pube jaua refers to the eastward seasonal migration from the district of western part of West Bengal like Bankura and Purulia district to Purba Bardhaman and Hooghly district.
}

\footnotetext{
${ }^{3}$ Boro paddy is a Rabi crop, popularly known as winter rice, cultivated under irrigation facilities from November to May (Singh, 2002).

${ }^{4}$ Sardar is a Bengali term, which is used to denote a leader of a group.
} 


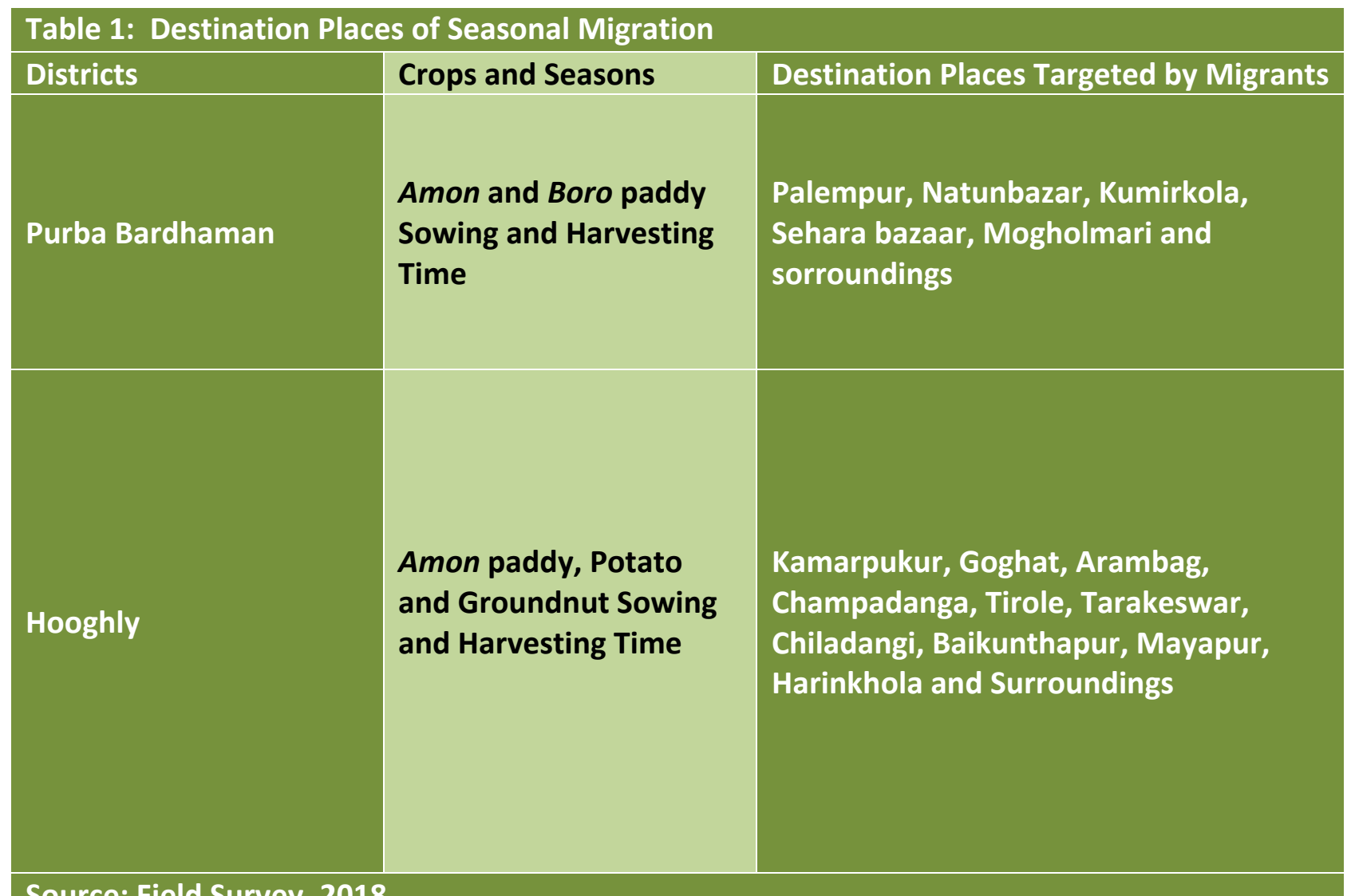

Source: Field Survey, 2018

\section{Factors of Seasonal Migration}

\section{Poor Status of Agricultural Land Holdings}

Land and its productivity are considered as a natural capital which indicates the economic stability of the households. Among the 30 households, $33.34 \%$ of households are landless, and only $26.66 \%$ have more than 10 katha $^{6}$ to 1 bigha $^{7}$ of agricultural land, which is marginal (Table 2). In the study area and its surrounding, Etel type lateritic soil ${ }^{8}$ is found, which is less productive, thereby, restricting paddy production, and $80 \%$ of the agricultural land remain unproductive due to lack of irrigation facilities (DHDR, 2007). Therefore, poor women find it as an easy option to engage in agricultural labour work at distant places for income generation for their families.

\footnotetext{
${ }^{6} 1$ Katha $=0.00665$ Hectare

${ }^{7} 1$ Bigha $=0.133$ Hectare
}

\section{Monoculture System and Limited Access to Irrigation Facilities}

Erratic monsoonal rainfall, dry porous lateritic soil, undulating surface induce the necessity of irrigation facilities for crop production, but it has limited scope in Hirbandh block. Therefore, rainfed Amon Paddy (July - November) is the main crop with low and varying production amount associated with inferior technology and traditional seeds, which provides little chances for the poor, illiterate women to get the return from own marginal land. In Hirbandh block, monocrop and more than one cropped areas are $78.67 \%$ and $21.33 \%$ respectively, while for the mouza these are $80.8 \%$ and $19.20 \%$ (Figure 2). Hence, job opportunity for agricultural labourers is significantly less (about 10-20 working days or less) and uncertain due to prevailing monoculture.

${ }^{8}$ Etel soils consists clay between $75-90 \%$ and because of significant clay component, it is named as Etel in West Bengal. 


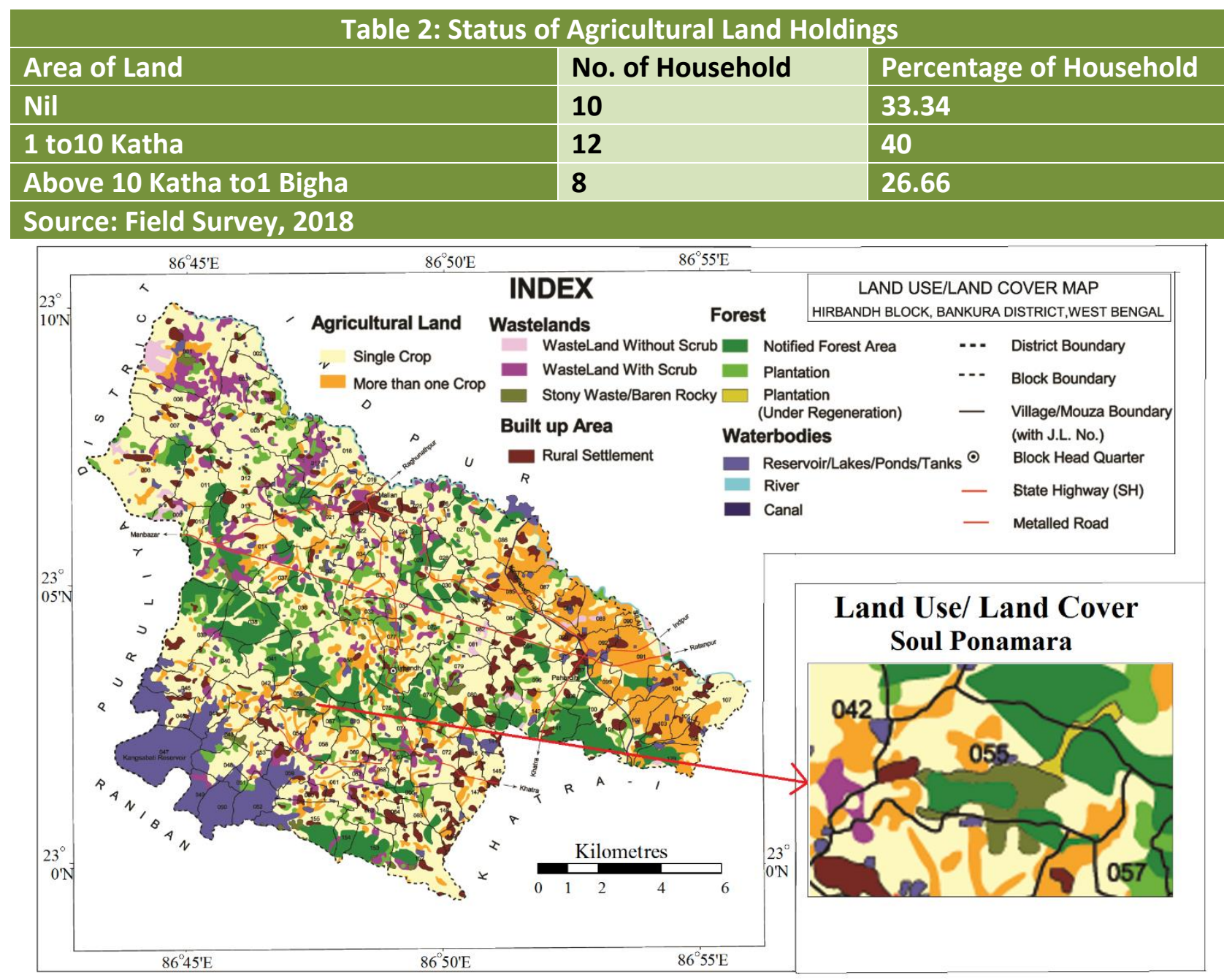

Figure 2: LULC Map of Hirbandh Block with enlarged view of Soul Ponamara Mouza in inset sowing predominance of single crop agricultural land after forest cover Source: Modified after Land and Land Reform Department, Government of West Bengal, 2013

\section{Limited Job Opportunity and Surplus Labour in Study Area and Surroundings}

In the study area other than agricultural activities, the available work opportunities are confined in the construction sector and Mahatma Gandhi National Rural Employment Guarantee Act (MGNREGA) scheme based activities. MGNREGA aims to increase the protection of people's livelihoods in rural areas by guaranteeing 100 days of wage employment in a financial year for adult members of rural households to perform unskilled manual work (Ministry of Rural Development, Government of India, 2020). However, in reality, it offers limited days (10-15 days on average) of jobs, therefore,
MGNREGA's 'job security' in the study area does not make sense (Ministry of Rural Development, Government of India, 2020). Construction and other informal daily labour sectors are highly male-dominated, so it puts limits on job availability to the women workers. Again interior location and absence of adequate transport facilities at inter-village level discourage them from moving locally for work. MGNREGA scheme is not very popular among the women labourers because of its variability and short term nature. In the local area, they get on an average of 15 days of work. Besides, landless or marginal Scheduled Castes and Scheduled Tribes population of Hirbandh block share $55.63 \%$ (DPCA, 2011) of the total population resulting 
surplus labour of women as well. Subsequently, they tend for seasonal migration to work as an agricultural labourer aimed at maintaining their livelihood.

\section{Popular Trend of Seasonal Migration}

Seasonal migration has been considered as a livelihood strategy by the people of the study area, and it can be traced back to the 1980s mainly dominated by male members. Development of transport and communication system, application of HYV seeds, modern technology and extension of irrigation facilities by Damodar Valley Corporation and Kangsabati River barrage especially after the 1980s paved the way for the development of the Hooghly, Purba Barddhaman and eastern portion of the Bankura districts as an agriculturally prosperous area (Rogaly et al., 2002). It had created an enormous demand for labour on a seasonal basis. Along with this increasing level of wage, improvement of the working environment, reduction of the wage gap between male and female, continuity and consistency of seasonal works, an excellent social network between group members and landlords at destination places acted as pull factors for their migration. Women of this mouza are accustomed to seasonal migration from their early childhood that not only increases the chances of migration but also the scale and volume of migration.

\section{Poor Economic Condition of Families}

Among the total households, $16.67 \%$ of households have an annual income below INR 15,000 , and about $50 \%$ of the households have income above INR 20,000. Rest of the households have an income ranges from INR 15,000 to 20,000 . According to DHDR (2007), in Hirbandh block, the percentage of families living below the poverty line (BPL) is $49.95 \%$ which is higher than district average (41.52\%), and during the field survey, we observed that the whole household belong to BPL category. That is why

\footnotetext{
9 Indira Awaas Yojana is now known as the Prime Minister's Rural Housing Scheme. It is a social welfare program designed by the Government of India to provide housing to the rural poor in India.
}

women started engaging in income generation process for ensuring their household food security. Working days are also significantly less in the local area in construction and agriculture sector for low infrastructural development of this block. Hence, to survive within this environment, they migrate to the nearby district (Hussain et al., 2020; Keshri and Bhagat, 2010). About $10 \%$ of the respondents said that sometimes they have to (1to 2 months/year) remain hungry for one time a day or spend their life with a single bow of rice. They mainly consume carbohydrates (rice and potato), and protein intake is very meagre in their diet (ones or two days in a week). Most of the houses (90\%) are made of mud with a thatch roof having no sanitation facilities. Several initiatives like Indira Awaas Yojana, ${ }^{9}$ Swacch Bharat Mission, ${ }^{10}$ Food security schemes ${ }^{11}$ and employment guarantee schemes had been introduced from time to time for improvement of their living conditions. However, these schemes failed to make any remarkable differences in their daily living conditions.

\section{Wage Gap and Continuity of Work}

In the local area, the supply of labour is high than its demand. Hence, bargaining for a wage is almost absent, and landowners take the opportunity of surplus labour after hiring women labourers at a meagre wage rate. However, rice and potato belts of Purba Bardhaman and Hooghly district attract both the male and female workers as the wage rate is relatively high, and there is no wage gap between male and female. The migrant labours get an average of INR 200 per day, and the wage gap between the places of origin and destination is double. The respondents get work opportunity for only 10-15 days in their village and surroundings, which is very small and uncertain about fulfilling their basic needs. Nevertheless,

10 Swacch Bharat Mission is a nationwide campaign launched by the Government of India in 2014 to eliminate open defecation and improve solid waste management.

${ }^{11}$ Food security ensuring adequate food supply to people, especially those deprived of basic nutrition. This is a major concern for food security in India and the United Nations. 
in destination place, they get work for 20-25

days regularly in each season.

\begin{tabular}{|l|l|l|}
\hline \multicolumn{2}{|c|}{ Table 3 Level of Annual Income of the Household } \\
\hline Income (INR) & No. of Household & Percentage of Household \\
\hline Below 15000 & $\mathbf{5}$ & 16.67 \\
\hline 15000 to 20000 & 10 & 33.33 \\
\hline 20000 to 25000 & 12 & 40 \\
\hline Above 25000 & 3 & 10 \\
\hline Source: Field Survey, 2018 & & \\
\hline
\end{tabular}

\section{Low level of Education}

Generally high level of education ensures people engagement as other workers in the organised or informal sectors (service and others). In the study area, overall literacy is very low (42.04\%), and women literacy is only $30.40 \%$ (DPCA, 2011). Among the total respondents, $66.67 \%$ are illiterate, and $20 \%$ of women have education level up to class IV. Only a meagre percentage share completed up to class VIII. So illiterate poor women with little exposure and skills to absorb in other work sectors practice seasonal migration for sustaining their livelihood.

\section{Livelihood Strategy}

Livelihood strategy directly determines poverty (Fernando \& Gunasekara, 2019). Poor women of Soul Ponamara mouza opted seasonal migration as a livelihood strategy for generation of job opportunity and income in the agricultural labour sector.

\section{Job Opportunity}

Job opportunity in Soul Ponamara mouza is limited and confined to Amon paddy cultivation, construction sector and MGNREGA scheme based works. Uncertain and variable production of Amon paddy secure less working days and construction sector is mainly male-dominated. Again MGNREGA scheme is also insignificant in this mouza, and villagers are not interested in it as they have a tendency to migrate seasonally to the nearest districts. Therefore, poor women of
Soul Ponamara mouza prefer to migrate for four to six times a year to Purba Bardhaman and Hooghly districts during the sowing and harvesting season of selected crops. They reside in the job site for a period of 20-25 days for each time (Table 4). Hence, these job opportunities help to generate income for securing their livelihood (Ellis, 2008), and it helps to fight existing poverty. In the local area, they get on an average 15 days of work or $11.54 \%$ among the total working days (approximately 130 days/year). However, due to their habit of seasonal migration, they enjoy 115 days (approximately) of work or $88.46 \%$ of the total working days Hence, their primary source of job opportunity is associated with seasonal migration. 


\begin{tabular}{|c|c|c|c|c|c|}
\hline \multirow[t]{4}{*}{ Working Day } & \multirow[t]{2}{*}{ Season } & \multicolumn{2}{|l|}{ Paddy } & \multirow[t]{2}{*}{ Potato } & \multirow[t]{2}{*}{ Groundnut } \\
\hline & & Amon & Boro & & \\
\hline & Sowing & 20-25 (June -July) & $\begin{array}{l}15-20 \\
\text { (December- } \\
\text { January) }\end{array}$ & $\begin{array}{l}\text { 15-20 (October- } \\
\text { November) }\end{array}$ & $\begin{array}{l}\text { 5-10 (December- } \\
\text { January) }\end{array}$ \\
\hline & Harvesting & $\begin{array}{l}20-25 \text { (October- } \\
\text { November) }\end{array}$ & 15-20 (April-May) & $\begin{array}{l}15-20 \\
\text { (February- } \\
\text { March) }\end{array}$ & $\begin{array}{l}\text { 5-10 (July - } \\
\text { August) }\end{array}$ \\
\hline
\end{tabular}

\section{Percentage of Job Opportunity}

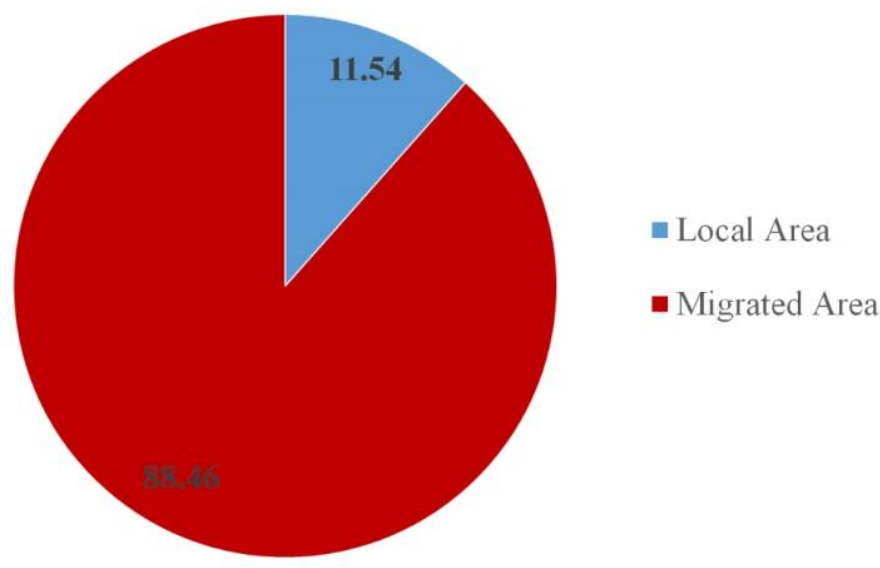

Figure 3: Percentage of Job Opportunity Source: Field Survey, 2018

\section{The Opportunity of Income Generation}

Available job opportunity in the destination places ensures economic gain, which is much needed for the family of women agricultural workers. It is already stated that all household in this mouza are BPL families and are depended on agricultural labour work to manage their household expenditure. Among the total respondents, $90 \%$ have an annual income below INR 18000 , at the same time, only $10 \%$ of the respondents have income above INR 18000. Male members of the family spend approximately half of their income in smoking and liquor consumption which puts an extra burden on the women to maintain the household. Hence, women are also critical economic partners with the male members in the household. Among the 30 women respondents, about 67 per cent of them have a share of above $50 \%$ of the family income and approximately $7 \%$ of women have shared more than $70 \%$ of their family income. Again, women who share above $70 \%$ income of the household are the primary income earner of their family as in most of the cases either they are a widow or their husband is ill. No other supportive members are there for earning. A small amount of savings nearly INR 500 to INR 700 of the WALS from this activity is very crucial to continue their household in the lean season. Their economic independence helps to cope up with food insecurity and sustainability of their livelihood. 


\begin{tabular}{|c|c|c|c|c|c|}
\hline \multicolumn{3}{|c|}{ Income from Agricultural Labour Work } & \multicolumn{3}{|c|}{ Share of Household Income } \\
\hline Income (INR) & $\begin{array}{l}\text { No. of } \\
\text { Women }\end{array}$ & $\begin{array}{l}\text { Percentage of } \\
\text { Women }\end{array}$ & $\begin{array}{l}\text { Percentage of } \\
\text { Share }\end{array}$ & $\begin{array}{l}\text { No. of } \\
\text { Women }\end{array}$ & $\begin{array}{l}\text { Percentage of } \\
\text { Women }\end{array}$ \\
\hline Below 12000 & 7 & 23.34 & Below 50 & 10 & 33.34 \\
\hline $12000-15000$ & 10 & 33.33 & $50-70$ & 18 & 60 \\
\hline $15000-18000$ & 10 & 33.33 & $70-90$ & 1 & 3.33 \\
\hline Above 18000 & 3 & 10 & Above 90 & 1 & 3.33 \\
\hline
\end{tabular}

\section{Conclusion}

Seasonal migration towards agriculturally prosperous eastern districts is the primary livelihood strategy of women workers in Soul Ponamara mouza to ensure their livelihood. Though MGNREGA scheme (2018-2019) in Bankura district is very much successful (Siddiqui, 2019) but the villagers of this study area get less opportunity of work in Soul Ponamara mouza which clearly indicates a regional disparity in implementation of this scheme at the local level. Maximum job opportunity, huge wage gap in-between origin and destination places, high wages, huge labour demand and availability of work attracted women to migrate seasonally, and it is becoming a trend among them. This type of seasonal migration harms not only their children's education but their overall future which is reflected through the low literacy level for both men and women. The study confirms that mobility of WALs is very much linked with their socio-economic status. Again at present popularity of using agricultural machinery poses a threat to their occupation as agricultural labourers. Therefore, the creation of new job opportunities should be the priority of the local administrative bodies within this challenging situation associated with limited resources. A well-knitted cluster-based programme can be formulated through exploring the new ventures like horticulture, dry farming, homestead gardening and rural tourism in the study area after adopting a bottom-up approach for sustainable livelihood.

\section{References}

Adhikari, B., Bag, M. K., Bhowmick, M. K., \& Kundu, C. (2011). Status paper on rice in West Bengal. Rice Research Station, Government of West Bengal,

India. https://www.researchgate.net/publicatio n/255742981_Status_Paper_on_Rice_in_West_ Bengal

Agarwal, B. (1990). Social security and the family: Coping with seasonality and calamity in rural India. The Journal of Peasant Studies, 17(3), 341-412.

https://doi.org/10.1080/03066159008438426

Asfaw, W., Tolossa, D., \& Zeleke, G. (2010). Causes and impacts of seasonal migration on rural livelihoods: Case studies from Amhara Region in Ethiopia. Norsk Geografisk Tidsskrift, 64(1), 58-70.

https://doi.org/10.1080/00291950903557696

Beck, T. (1989). Survival strategies and power amongst the poorest in a West Bengal Village. IDS Bulletin, 20(2), 23-32.

https://doi.org/10.1111/j.1759-

5436.1989.mp20002004.x

Berchoux, T., Watmough, G. R., Hutton, C. W., \& Atkinson, P. M. (2019). Agricultural shocks and drivers of livelihood precariousness across Indian rural communities. Landscape and Urban Planning, 189, 307-319.

https://doi.org/10.1016/j.landurbplan.2019.04. 014

Biswal, M. (2020). Impact of seasonal migration on children of a scheduled caste community in 
western Odisha, India. EPRA International Journal of Economic and Business Review, 7278. https://doi.org/10.36713/epra3055

Census of India. (2011a). Bankura district census Abstract. http.//censusindia.gov.in on, accessed on $20 / 5 / 2018$

Census of India. (2011b). Bankura district village directory. http.//censusindia.gov.in on, accessed on 20/4/2019

Chandrasekhar, C. P., \& Ghosh, J. (2007, September 25). Dealing with short-term migration. The Hindu, Business Line, p. 12. https://www.thehindubusinessline.com/todayspaper/tp-opinion/Dealing-with-short-termmigration/article20176527.ece

Chandrasekhar, S., \& Sahoo, S. (2018). Shortterm migration in rural India: The impact of nature and extent of participation in agriculture (No. 2018-016). Indira Gandhi Institute of Development Research, Mumbai, India.

http://www.indiaenvironmentportal.org.in/files /file/Short-

term\%20Migration\%20in\%20Rural\%20India.pdf

De Haan, A., Brock, K., \& Coulibaly, N. (2002). Migration, livelihoods and institutions: Contrasting patterns of migration in Mali. Journal of Development Studies, 38(5), 3758. https://doi.org/10.1080/002203804123313 22501.

Debnath, M. (2020). Exploring the behavior of seasonal agricultural migrants in the Rarh region of West Bengal, India. Spatial Information Research. https://doi.org/10.1007/s41324-020-00338-6

Debnath, M., \& Nayak, D. K. (2020). Assessing drought-induced temporary migration as an adaptation strategy: Evidence from rural India. Migration and Development, 1-22. https://doi.org/10.1080/21632324.2020.17974 58

Deshingkar, P., \& Start, D. (2003). Seasonal migration for livelihoods in India: Coping, accumulation and exclusion. Overseas Development Institute..
District Human Development Report (2007).

Development and Planning Department, Government of West Bengal. Kolkata.

District Statistical Handbook(2014). Department of Statistics and Programme Implementation, Government of West Bengal.

Ellis, F. (2008). The determinants of rural livelihood diversification in developing countries. Journal of Agricultural Economics, 51(2), 289-302. https://doi.org/10.1111/j.14779552.2000.tb01229.x

Fernando, R. L. S., \& Gunasekara, H. O. C. (2019). Poverty reduction efforts in siyambalanduwa divisional secretariat in Monaragala district in Sri Lanka: Problems and prospects. In R. et al (Ed.). Social Welfare Policies and Programmes in South Asia (pp. 195-213). https://doi.org/10.4324/9780429323041-13

Filep, B. (2009). Interview and translation strategies: Coping with multilingual settings \& data. Social Geography, 4(1), 59-70. https://doi.org/10.5194/sg-4-59-2009

Garikipati, S. (2008). Agricultural wage work, seasonal migration and the widening gender gap: Evidence from a semi-arid region of Andhra Pradesh. European Journal of Development Research, 20(4), 629-648. https://doi.org/10.1080/09578810802464870

Gautam, Y. (2017). Seasonal migration and livelihood resilience in the face of climate change in Nepal. Mountain Research and Development, 37(4), 436. https://doi.org/10.1659/mrd-journal-d-1700035.1

Ghosh, R. \& Mal, S. (2017). Impacts of rural labour migration of south Bengal: A case study of Bankura and Purulia districts of West Bengal, India. Global Journal of Human -Social

Science,17(7), 25-32.

Gill, G. J. (2003). Seasonal labour migration in rural Nepal : a preliminary overview. https://www.worldcat.org/title/seasonallabour-migration-in-rural-nepal-a-preliminaryoverview/oclc/56067783\&referer=brief_results 
Gundappa, \& Dsouza, A. A. (2014). Migration of agricultural labourers and its impact on the farming sector. Journal of Social Sciences, 6(3), 202-213. http://repository.kln.ac.lk/handle/123456789/1 1028

Hazell, P., \& Ramasamy, C. (1991). The green revolution reconsidered: The impact of highyielding rice varieties in South India. https://www.cabdirect.org/cabdirect/abstract/ 19926713240

Hussain, A., Memon, J. A., \& Hanif, S. (2020). Weather shocks, coping strategies and farmers' income: A case of rural areas of district Multan, Punjab. Weather and Climate Extremes, 30, 100288. https://doi.org/10.1016/j.wace.2020.100288

Hussain, M. (1996). Systematic agricultural geography. Rawat Publications, New Delhi, India.

Islam, M., Kashem, S., Morshed, S., Rahman, M., \& Das, A. (2019). Dynamics of seasonal migration of rural livelihood; capital formation perspective. Advanced Journal of Social Science,5(1),81-92.

https://doi.org/10.21467/ajss.5.1.81-92

Keshri, K., \& Bhagat, R. B. (2010). Temporary and seasonal migration in India. Genus, 66(3), 25-45. https://doi.org/10.4402/genus-207

Keshri,K., \& Bhagat, R.B. (2012). Temporary and seasonal migration: Regional pattern, characteristics and associated factors. Economic and Political Weekly, 47(4), 81-88.

http://www.jstor.org/stable/41419769

Keshri, K., \& Bhagat, R. B. (2013).

Socioeconomic determinants of temporary labour migration in India: A regional analysis. Asian Population Studies, 9(2), 175-195. https://doi.org/10.1080/17441730.2013.79729 4

Khatun, D., \& Roy, B. C. (2016). Rural livelihood diversification in West Bengal: Nature and extent. Agricultural Economics Research Review, 29(2), 183.

https://doi.org/10.5958/09740279.2016.00046.x
Lindstrom, D. P., \& Ramírez, A. L. (2010).

Pioneers and followers: Migrant selectivity and the development of U.S. migration streams in Latin America. Annals of the American Academy of Political and Social Science, 630(1), 53-77. https://doi.org/10.1177/0002716210368103

Ministry of Rural Development, Government of India (2020). Mahatma Gandhi National Rural Employment Guarantee Act.

https://mnregaweb2.nic.in/netnrega/homestcit i.aspx?state_code $=32 \&$ state_name $=$ WEST\%20B ENGAL

Mishra, D.K. (2016). Seasonal migration from Odisha: a view from the field. In D.K. Mishra (Eds.), Internal migration in Contemporary India (pp. 263-290). Sage Publiation India Pvt. Ltd.

Mishra, D. K. (2020). Seasonal migration and unfree labour in globalising India: Insights from Field surveys in Odisha. The Indian Journal of Labour Economics.

https://doi.org/10.1007/s41027-020-00277-8

National Bureau of Soil Survey and Land use Planning (2010). Indian Council of Agricultural Research. Retrieved from

https://www.nbsslup.in/

Panda, P., \& Agarwal, B. (2005). Marital violence, human development and women's property status in India. World Development, 33(5), 823-850.

https://doi.org/10.1016/j.worlddev.2005.01.00 9

Panda, S. S., \& Mishra, N. R. (2018). Factors affecting temporary labour migration for seasonal work: A review. Management Research Review, 41(10), 1176-1200. https://doi.org/10.1108/mrr-04-2017-0104

Rademacher-Schulz, C., Schraven, B., \& Mahama, E. S. (2014). Time matters: Shifting seasonal migration in Northern Ghana in response to rainfall variability and food insecurity. Climate and Development, 6(1), 4652.

https://doi.org/10.1080/17565529.2013.83095 5

Rafique, A. (2003). Floods, poverty and, seasonal migration. Economic and Political 
Weekly, 38(10), 943-945.

http://www.jstor.org/stable/4413304

Rai, P. (2020). Seasonal masculinities: Seasonal labour migration and masculinities in rural western India. Gender,Place \& Culture, 27(2), 260-280.

https://doi.org/10.1080/0966369X.2019.16401 88

Ravenstein, E. G. (1889). The laws of migration. Journal of the Royal Statistical Society, 52(2), 241. https://doi.org/10.2307/2979333

Regmi, K., Naidoo, J., \& Pilkington, P. (2010). Understanding the processes of translation and transliteration in qualitative research. International Journal of Qualitative Methods, 9(1), 16-26.

https://doi.org/10.1177/160940691000900103

Rogaly, B. (2010). Workers on the move: Seasonal migration and changing social relations in rural India. 2074, 20-29. https://doi.org/10.1080/741922628

Rogaly, B., Biswas, J., Coppard, D., Rafique, A., Rana, K., \& Sengupta, A. (2001). Seasonal migration, social change and migrants? Rights: Lessons from West Bengal. Economic and Political Weekly, 36(49), 4547-4559. http://www.jstor.org/stable/4411446

Rogaly, B., \& Coppard, D. (2003). "They used to go to eat, now they go to earn": The changing meanings of seasonal migration from Puruliya District in West Bengal, India. Journal of Agrarian Change, 3(3), 395-433. https://doi.org/10.1111/1471-0366.00060

Rogaly, B., Coppard, D., Rafique, A., Rana, K., Sengupta, A., \& Biswas, J. (2002). Seasonal migration and welfare/illfare in eastern India: A social analysis. Journal of Development Studies, 38(5), 89-114. https://doi.org/10.1080/002203804123313225 21

Serrat, O. (2017). The Sustainable Livelihoods Approach. In O. Serrat (Ed.), Knowledge Solutions (pp. 21-26). https://doi.org/10.1007/978-981-10-0983-9_5

Siddiqui, K. (2019, December 16). Bankura tops nation in MGNREGA performance. The
Statesman, p. 14.

https://www.thestatesman.com/bengal/bankur a-tops-nation-in-mgnrega-performance1502834221.html

Singh, U. P. (2002). Boro rice in Eastern India. rice-wheat consortium regional technical coordination committee meeting. 10-14 February 2002. Rice-Wheat Consortium for the Indo-Gangetic Plains, New Delhi, India.

Singh, N. P., Singh, R. P., Kumar, R., Padaria, R. N., Singh, A., \& Varghese, N. (2011). Labour migration in Indo-Gangetic plains: Determinants and impacts on socio-economic welfare.

Agricultural Economics Research Review, 24, 449-458.

http://dx.doi.org/10.22004/ag.econ.119396

Sundari, S. (2005). Migration as a livelihood strategy: A gender perspective. Economic and Political Weekly, 40(22), 2295-2303. http://www.jstor.org/stable/4416709

Temple, B. \& Young, A. (2004). Qualitative research and translation dilemmas. Qualitative Research, 4(2), 161-178.

https://doi.org/10.1177/1468794104044430

Thapa, R., \& Yadav, S. K. (2015). Rural labour migration in India : Magnitude and characteristics. International Journal of Applied Research, 1(2), 114-118.

http://www.shram.org/uploadFiles/201708240 20611.pdf

Walker, T. S., \& Ryan, J. G. (1990). Village and household economies in India's semi-arid tropics. Baltimore.: The Johns Hopkins University Press.

Zelinsky, W. (1971). The hypothesis of the mobility transition. Geographical Review, 61(2), 219. https://doi.org/10.2307/213996

\section{Conflict of Interest}

None

\section{About the Authors}

Debmita Nandi's main research area is focused on livelihood condition of rural working women in Bankura district. She has already published two papers related to her research area. 
Dr. Sumana Sarkar bears expertise in the field of application of spatial database in rural development and planning. She is also working in the field of livelihood issues, education and empowerment of rural women. She has contributed more than thirteen research articles.

\section{Acknowledgements}

The first author would like to express her deep gratitude to the University Grants Commission, New Delhi (India) for granting fellowship for the entire research work. Both the authors are thankful to the people of Soul Ponamara mouza for their cooperation during the field survey. The authors would also like to thank the editors and anonymous reviewers for their detailed comments and observations that significantly helped to enrich the manuscript.

\section{Author Contribution Statement}

Debmita Nandi and Dr Sumana Sarkar conceptualised the research and methodology. The first author, Debmita Nandi collected primary data through field survey; she was also involved in the analysis of the data and preparation of tables, maps and charts and framing the initial draft of the manuscript. The second author, Dr. Sumana Sarkar, supervised the research work and assisted in shaping the final draft of the manuscript after editing and reviewing it. 